\section{KAROLINA KACZMAREK}

Uniwersytet im. Adama Mickiewicza w Poznaniu, Polska https://orcid.org/0000-0002-4736-4990
Copyright and License: Copyright by Instytut Języka Polskiego PAN, Kraków 2021. This article is published under the terms of the Creative Commons Attribution - NoDerivatives 4.0 International (CC BY- ND 4.0) License (https:// creativecommons.org/licenses/by-nd/4.0/legalcode.pl).

\title{
MNIEJSZOŚĆ NARODOWA CZY NARODOWOŚĆ? WSPÓŁCZESNA POLITYKA TERMINOLOGICZNA NA WĘGRZECH JAKO ODZWIERCIEDLENIE TYSIĄCLETNIEJ TRADYCJI PAŃSTWA WIELONARODOWEGO I KONSEKWENCJA TRAKTATU W TRIANON
}

Słowa kluczowe: Węgry, mniejszość narodowa, narodowość, polityka terminologiczna.

\section{STRESZCZENIE}

Celem artykułu jest wskazanie na przyczyny zmian terminologicznych w najnowszych ustawach węgierskich dotyczących mniejszości narodowych zamieszkujących Węgry. Wykazano tu związek obecnej polityki terminologicznej rządu na Węgrzech z sytuacją diaspor węgierskich poza granicami kraju. Dotyczy to zwłaszcza dwóch terminów: mniejszość narodowa i narodowość. Przywołano historyczne procesy wpływające na powstanie wielonarodowych i wielojęzycznych Węgier, kształtowanie się systemu prawnego uwzględniającego współistnienie wielu narodowości i języków na terenie kraju, przyczyny konfliktów i próby wdrożenia rozwiązań czy to uwzględniających interesy różnych narodowości, czy to mających na celu wprowadzenie dominacji narodowości i języka węgierskiego. Po zmianie systemu politycznego pod koniec lat 80. rząd węgierski podejmował wiele kroków mających na celu poprawę sytuacji mniejszości węgierskich, które mieszkają poza ojczyzną od czasu podpisania traktatu w Trianon w 1920 roku. Taka polityka rządu miała też wpływ na sytuację mniejszości narodowych zamieszkujących obszar Węgier. Rozpoczęto prace nad nowym, nowoczesnym prawem regulującym status mniejszości narodowych, które miało stać się wzorcem dla innych krajów i argumentem w negocjacjach dotyczących mniejszości węgierskich w sąsiednich krajach. W dyskusjach nad projektem nowej ustawy o mniejszościach narodowych, ostatecznie uchwalonej w 1993 roku, powracano do najlepszych tradycji i najkorzystniejszych - dla narodowości - idei wyrażonych w ustawach wprowadzanych w XIX wieku. W przeciwieństwie do idei madziaryzacji, pojawiającej się w niektórych okresach historii Węgier, nowe prawo miało przeciwdziałać asymilacji narodowości: wspierać je strukturalnie w pielęgnowaniu własnej kultury i utrzymaniu odrębnej tożsamości. W nowej konstytucji Węgier, ogłoszonej w 2011 roku, przeprowadzono zamianę funkcjonującego wcześniej terminu mniejszość narodowa na - właśnie - narodowość. W kolejnych aktach prawnych konsekwentnie stosuje się już ten nowy termin. Znajduje to również odzwierciedlenie w tytule kolejnej ustawy „o narodowościach” uchwalonej jeszcze w 2011 roku. Trzeba tu widzieć celowe działanie o charakterze propagandowym. Zmiana terminu ma w symboliczny sposób podnieść status ludności węgierskiej mieszkającej poza granicami ojczyzny oraz zwrócić uwagę na fakt, że Węgry traktują tę ludność jako nieodłączną część jednego narodu węgierskiego. 


\section{WPROWADZENIE}

Królestwo Węgier przez setki lat zajmowało duży obszar Europy Środkowej, zamieszkiwała je ludność mówiąca różnymi językami i mająca odmienne zwyczaje. Ta sytuacja zmieniła się diametralnie w XX wieku. Przed zawarciem traktatu w Trianon w 1920 roku, który dla Węgier kończył I wojnę światową, 46\% ludności Węgier stanowiły mniejszości narodowe. Po jego zawarciu ta liczba zmniejszyła się do 10\%, a w 1930 roku mniejszości narodowe stanowiły ok. $6 \%$ populacji kraju (por. Kopyś 2018, 415). Stało się tak przede wszystkim na skutek zmian granic - $67 \%$ obszarów Węgier i $58 \%$ ludności zostało przyłączonych do innych państw ${ }^{1}$. Ponadto duża grupa ludności niewęgierskiej wyemigrowała z powodu trudności gospodarczych, niekorzystnego dla narodowości podziału ziemi po reformach rolnych oraz propagandy politycznej sąsiednich krajów. W konsekwencji Węgry z państwa wielonarodowościowego zmieniły się w państwo niemal całkowicie jednorodne. $Z$ kolei poza granicami ojczyzny znalazła się ogromna rzesza ludności węgierskiej, która stała się mniejszością narodową w Rumunii, na Słowacji, na Ukrainie i w pozostałych krajach ościennych.

Mimo niekorzystnych warunków niektóre grupy ludności niewęgierskiej zachowały swoją odrębną tożsamość do dnia dzisiejszego. Zarówno węgierska Ustawa LXXVII z 1993 roku o mniejszościach narodowych i etnicznych (1993. évi LXXVII. törvény a nemzeti és etnikai kisebbségek jogairól), jak i wchodząca w jej miejsce Ustawa CLXXIX z 2011 roku o prawach narodowości (2011.évi CLXXIX. törvény a nemzetiségekjogairól) wyróżniły 13 grup obejmujących rdzennych mieszkańców Węgier i mających status mniejszości narodowej. Są to grupy: bułgarska, grecka, chorwacka, polska, niemiecka, ormiańska, romska, rumuńska, rusińska, serbska, słowacka, słoweńska i ukraińska.

Po zmianie systemu w 1989 roku rząd węgierski podejmował wiele kroków mających na celu poprawę sytuacji diaspory „potrianońskiej”, zwłaszcza w krajach ościennych. Miało to też wpływ na sytuację mniejszości narodowych zamieszkujących obszar Węgier. Nowe prawo miało być wzorcem dla innych krajów i argumentem w negocjacjach dotyczących mniejszości węgierskich w sąsiednich krajach².

Rządy partii FIDESZ, zwłaszcza od wyborów w 2010 roku, charakteryzują się dużą dynamiką w zakresie propagowania symboli nawiązujących do okresu sprzed zawarcia traktatu w Trianon w 1920 roku, co uwidacznia się m.in. w terminologii

\footnotetext{
${ }^{1}$ Terytorium Węgier - nie licząc Chorwacji - zmniejszyło się z 282 tys. do 93 tys. $\mathrm{km}^{2}$, natomiast liczba ludności - z ponad 18,2 mln do 7,9 mln. Największy obszar przypadł Rumunii (102 tys. km² i 3,5 mln ludzi), Jugosławia, oprócz Chorwacji i Slawonii, zyskała 20 tys. $\mathrm{km}^{2}$ i $1,5 \mathrm{mln}$ mieszkańców, Austria -4 tys. $\mathrm{km}^{2}$ i 200 tys. ludzi. Niewielkie obszary otrzymały też Polska i Włochy (Romsics 2018, 360-361).

${ }^{2}$ Jak zauważają Dominik Héjj i Bogusław Olszewski $(2015,571)$, „trzynaście narodowości żyjących obecnie na Węgrzech, według dość powszechnej opinii funkcjonuje w bardzo dobrych, zarówno pod względem prawnym, jak i finansowym, warunkach. Rząd chętnie wspiera inicjatywy lokalne, dotuje budowy nowych szkół, ośrodków kulturalnych itp. Narodowości posiadają swoje lokalne media, w tym program czwarty publicznego radia. Wprowadziły do parlamentu 13 rzeczników, którzy w ich imieniu dbają o interesy danej społeczności”.
} 
prawnej i urzędowej ${ }^{3}$. Zgodnie z tym trendem, który można nazwać polityką terminologiczną, w nowej konstytucji Węgier z 2011 roku (Magyarország Alaptörvénye, 2011. április 25.) w miejsce terminu mniejszość narodowa $i$ etniczna 'nemzeti és etnikai kisebbség' wprowadzono termin narodowość 'nemzetiség'. Ta zmiana miała - z jednej strony - wskazywać, że mniejszości narodowe zamieszkujące obszar Węgier stanowią jego ważną część i państwo popiera ich dążenie do utrzymania własnej tożsamości, a z drugiej strony - co należy uważać za najbardziej istotny wymiar symboliki nowej terminologii - rząd po raz kolejny zwrócił przez to uwagę na korzenie i status diaspory węgierskiej, a tym samym zaakcentował swoje oczekiwania w zakresie realizacji praw narodowościowych tej grupy ludności ${ }^{4}$.

Po wprowadzeniu do konstytucji węgierskiej nowej terminologii rozpoczął się proces jej upowszechniania. Termin narodowość w znaczeniu mniejszości narodowej zaczęto stosować w pozostałych aktach prawnych, nazwach instytucji, w thumaczeniach unijnych i innych dokumentach międzynarodowych. Na skutek tej tendencji tytuł ustawy z 2011 roku, wprowadzonej w miejsce obowiązującej od 1993 roku Ustawy o mniejszościach narodowych i etnicznych, zmieniono na Ustawa o prawach narodowości. Konsekwentnie, zamiast funkcjonującego wcześniej w prawie terminu samorząd mniejszości, wprowadzono samorzą narodowościowy, instytucje edukacyjne mniejszości zastąpiono narodowościowymi instytucjami edukacyjnymi, zamiast instytucji kulturalnych mniejszości zaczęto używać wyrażenia narodowościowe instytucje kultury itd.

\section{CZYM JEST MNIEJSZOŚĆ NARODOWA I NARODOWOŚĆ - DEFINICJE PRAWNE}

Zarówno prawa poszczególnych państw, jak i prawo międzynarodowe zawierają liczne regulacje odnoszące się do mniejszości narodowych. Nie ma natomiast jasnych kryteriów, na podstawie których można ustalić przynależność do takich mniejszości. Rezolucja Parlamentu Europejskiego z dnia 13 listopada 2018 r. w sprawie norm minimalnych dla mniejszości w UE (2020/C 363/03) w punkcie 35 określa, że

[...] mniejszości narodowe i etniczne są to grupy osób należących do mniejszości oraz mieszkających na tym samym terytorium i posiadających wspólną tożsamość, w niektórych przypadkach w wyniku zmian granic, a w innych w wyniku przebywania przez długi czas na obszarze, na którym udało się im zachować tożsamość.

\footnotetext{
${ }^{3}$ Podkreśla to również Dominik Héjj (2018, 236-237): „Ostatniego dnia maja 2010 r., a zatem dwa dni po zaprzysiężeniu drugiego rządu Viktora Orbána, Zgromadzenie Narodowe przyjęło ustawę o jedności narodowej, w myśl której diaspora stała się częścią jednolitego narodu węgierskiego". Zatem 4 czerwca w rocznicę podpisania traktatu z Trianon w 1920 roku, stał się świętem o nazwie „Narodowy Dzień Jedności” (Nemzeti Összetartozás Napja). Kluczem jest tutaj trudny do przetłumaczenia termin összetartozás oznaczający „tworzenie całości” - w tym kontekście: niepodzielnego państwa węgierskiego, a zatem Królestwa Węgier w granicach i liczebności sprzed Trianon.

${ }^{4} \mathrm{Na}$ ten aspekt wskazują również Dominik Héjj i Bogusław Olszewski (2015, 571): „Zmiana terminu «mniejszość» na «narodowość» ma swoje uzasadnienie w polityce Viktora Orbána. Zdaniem władz termin «narodowość», stosowany w XIX wieku, podkreśla wagę i pozycję danej społeczności”.
} 
W uzusie międzynarodowym podejmowano wiele prób zdefiniowania takich terminów jak mniejszość narodowa i etniczna czy narodowość ${ }^{5}$. Jednakże, wobec wielości propozycji, ciągle aktualne wydaje się stwierdzenie, że:

\footnotetext{
${ }^{5}$ Etniczność, chociaż jest pojęciem od dawna stosowanym w naukach społecznych, to - jak zauważa Małgorzata Bieńkowska-Ptasznik (2007, 324) - ciągle pozostaje terminem nieostrym i niejednoznacznym. Według Andrzeja Sadowskiego (1973, 186; por. Bieńkowska-Ptasznik 2007, 19) grupami etnicznymi nazywamy wszystkie trwałe postacie integracji społecznej, powstałej w wyniku obiektywnego procesu historycznego na gruncie języka, autentycznego lub domniemanego pochodzenia, religii i innych czynników, cechujące się poczuciem odrębności w stosunku do innych zbiorowości”. Według definicji Grzegorza Babińskiego etniczność to zespół cech grupowych. „Cechy te to na pewno pewien rodzaj więzi, chociaż niesprowadzalny do więzi prymordialnej, to również świadomość wspólnego pochodzenia i wspólnoty kulturowej i - oparte na tej świadomości - poczucie «my», oddzielające grupę od innych grup etnicznych, a także, w pewnych wymiarach, od «reszty świata»" (Bieńkowska-Ptasznik 2007, 324 cyt. za: Babiński 1998, 191).

Jak zauważa Grzegorz Janusz (2011, 95), w odróżnieniu od terminu obywatelstwo, które jest jednoznacznie określane przez prawo, narodowość wiąże się ze stanem świadomości każdego człowieka i z - wynikającą $\mathrm{z}$ tego stanu - jego identyfikacją z daną grupą etniczną. Zgodnie ze stanowiskiem Rady Unii Europejskiej pojęcie narodowość „,nie powinno ograniczać się wyłącznie do pojęcia obywatelstwa, ale powinno również obejmować przynależność do grupy, określoną przez jej kulturową lub językową tożsamość, lub jej związki z ludnością innego państwa" (Wspólne stanowisko z dnia 4 marca 1996 r. określone przez Radę na podstawie art. K.3 Traktatu o Unii Europejskiej w sprawie jednolitego stosowania definicji pojęcia uchodźca w art. 1 Konwencji genewskiej z dnia 28 lipca 1951 r. dotyczącej statusu uchodźców (96/196/WSiSW) Dziennik Urzędowy L 063, 13/03/1996 P. 0002-0007). Z kolei w Polsce wyrażenie narodowość zdefiniowano bardzo szeroko na potrzeby spisu powszechnego ludności w 2011 roku - w art. 2 pkt 6 ustawy z dnia 4 marca 2010 roku o narodowym spisie powszechnym ludności i mieszkań w 2011 r. (Dz.U. Nr 47, poz. 277). Według treści ustawy narodowość (przynależność narodowa lub etniczna) jest deklaratywną (opartą na subiektywnym odczuciu) cechą indywidualną każdego człowieka, wyrażającą jego związek emocjonalny (uczuciowy), kulturowy lub genealogiczny (ze względu na pochodzenie rodziców) z określonym narodem. Definicja zawarta w tej ustawie wywołała natomiast liczne kontrowersje. Wiele osób wykorzystało możliwość szerokiej interpretacji terminu i zadeklarowało w spisie narodowość śląską, co niektóre środowiska uznały za „demonstrację antypolskości”.

Również dość skomplikowaną kwestią staje się dokładne określenie, co oznaczają słowo naród czy określenie przynależność do Narodu Polskiego. Na to pytanie stara się odpowiedzieć Iwona Wrońska (2014, 271-272), która w tym celu przytacza m.in. interpretację Trybunału Konstytucyjnego (Wyrok Trybunału Konstytucyjnego z dnia 19 września 2008 roku, sygn. akt K 5/07). Według art. 4 Konstytucji RP z 1997 roku „1. Władza zwierzchnia w Rzeczypospolitej Polskiej należy do Narodu. 2. Naród sprawuje władzę przez swoich przedstawicieli lub bezpośrednio". Ponadto, w preambule Konstytucji $R P$, mającej moc normatywną, padają słowa: ,,[...] my, Naród Polski - wszyscy obywatele Rzeczypospolitej, zarówno wierzący w Boga będącego źródłem prawdy, sprawiedliwości, dobra i piękna, jak i nie podzielający tej wiary”. Powstaje tu jurydyczne znaczenie słowa naród w polskim porządku prawnym. $Z$ tych powodów pojęcie naród należałoby rozumieć, w myśl zasady clara non sunt interpretanda (to, co jasne, nie podlega interpretacji), że naród polski stanowią wszyscy obywatele Rzeczypospolitej Polskiej. Wydaje się natomiast, że taka interpretacja okazuje się jednak zbyt wąska dla potrzeb analizy dyskursu międzynarodowego i nie jest do końca zbieżna z innymi interpretacjami słowa naród. Z przytaczanych wcześniej definicji i aktów prawnych wynika, że o wiele częściej słowo naród jest rozumiane tak jak słowo narodowość, tj. bardziej na podstawie kryterium tożsamości niż obywatelstwa.

Zgodnie z art. 1 Konwencji Wspólnoty Niepodległych Państw o ochronie praw należących do mniejszości narodowych (1994) pod pojęciem osób należących do mniejszości narodowych należy rozumieć osoby stale zamieszkałe na terytorium jednej z umawiających się stron i mające jej obywatelstwo, które swoim
} 
współcześnie nie ma powszechnie uznawanej w stosunkach międzynarodowych definicji mniejszości. Taki stan rzeczy spowodowany został tym, że w odróżnieniu od obywatelstwa, które jest jednoznacznie określane przez prawo, narodowość stanowi stan świadomości każdego człowieka i wynikającą z tego stanu jego identyfikację z daną grupą etniczną (Janusz 2008, 95).

Wyraz narodowość ('nemzetiség') może mieć na Węgrzech co najmniej dwa znaczenia. Jedno z nich jest bliskie znaczeniu słowa obywatelstwo ('állampolgárság'), oznacza przynależność do jakiegoś narodu. Przy czym warto zauważyć, że zgodnie ze stanowiskiem Rady Unii Europejskiej z 4 marca 1996 roku $^{6}$ pojęcie narodowość nie powinno ograniczać się wyłącznie do pojęcia obywatelstwa, ale powinno również obejmować przynależność do grupy, określoną przez jej kulturową lub językową tożsamość, albo jej związki z ludnością innego państwa. Drugie znaczenie odnosi się natomiast do mniejszości narodowych zamieszkujących kraje Europy Środkowej, chodzi tu zwłaszcza o diasporę węgierską, odciętą od macierzy w 1920 roku. Takie rozumienie wynika z uwarunkowań historycznych. Termin narodowość pojawia się w prawodawstwie węgierskim już w XIX wieku. W pierwszym zdaniu Ustawy XLIV z 1868 roku o równych prawach narodowości (1868. évi XLIV. törvénycikk a nemzetiségi egyenjogúság tárgyában) czytamy:

Ponieważ wszyscy obywatele Węgier zgodnie z zasadami konstytucji w rozumieniu politycznym stanowią jeden naród, niepodzielny, jednorodny węgierski naród, każdy obywatel ojczyzny, niezależnie od tego do jakiej narodowości przynależy, jest jej równoprawnym członkiem.

Słownik języka węgierskiego wydany w drugiej połowie XIX wieku (Czuczor i Fogarasi 1862-1874) definiuje słowo narodowość jako specyfikę narodu w życiu obywatelskim, społecznym, moralnym i w zwyczajach, która jest ściśle powiązana z jego istnieniem, a której osłabienie i zaniknięcie spowoduje, że narodowość zatraci swoją oryginalność. Szczególnym atrybutem narodowości jest jej język.

Węgierska Ustawa o mniejszościach narodowych i etnicznych z 1993 roku, w § 1 (2) definiuje mniejszość narodową i etniczną jako

[...] taką grupę ludności zamieszkałą na obszarze Republiki Węgierskiej przez co najmniej sto lat, która jest w mniejszości w stosunku do pozostałej ludności państwa, członkowie tej grupy są węgierskimi obywatelami, mają język, kulturę i zwyczaje różniące się od pozostałych obywateli i mieszkańców Węgier i równocześnie tworzą taką wspólnotę, która dąży do ochrony tego dziedzictwa oraz dba o interesy swoich historycznie ukształtowanych wspólnot.

etnicznym pochodzeniem, językiem, kulturą, religią lub tradycją odróżniają się od pozostałej ludności danej strony. Definicję mniejszości narodowej zawiera też art. 1 dokumentu uchwalonego w Turynie w 1994 roku, a zatytułowanego Instrument Inicjatywy Środkowoeuropejskiej ochrony praw mniejszości. Opisuje on mniejszość narodową jako grupę mniejszą liczebnie od pozostałej części ludności w danym państwie, której członkowie, będący obywatelami danego państwa, mają etniczne, religijne lub językowe cechy odróżniające je od pozostałej części ludności i kierują się wolą zachowania własnej kultury, tradycji, religii lub języka.

${ }^{6}$ Wspólne stanowisko z dnia 4 marca 1996 r. określone przez Radę na podstawie art. K.3 Traktatu o Unii Europejskiej w sprawie jednolitego stosowania definicji pojęcia uchodźca $\mathrm{w}$ art. 1 Konwencji genewskiej z dnia 28 lipca 1951 r. dotyczącej statusu uchodźców, Dziennik Urzędowy L 063, 13/03/1996 P. 0002-0007. 
W nowej ustawie, która weszła w życie w 2011 roku, zamiast terminu mniejszość narodowa zastosowano już termin narodowość - zgodnie z nomenklaturą wykorzystywaną w węgierskiej konstytucji. Przestało również funkcjonować wyrażenie mniejszość etniczna ${ }^{7}$. Sama definicja okazuje się bardzo podobna pod względem treści do definicji z ustawy wcześniej obowiązującej, opuszczono natomiast zapis, że członkowie tej społeczności muszą być obywatelami Węgier. Według ustawy z 2011 roku (§ 1 ust. 1) narodowościa jest

[...] każda taka grupa ludności zamieszkałej na obszarze Węgier przez co najmniej sto lat, która jest w mniejszości w stosunku do pozostałej ludności państwa, członkowie tej grupy mają język, kulturę i zwyczaje różniące się od pozostałych obywateli i mieszkańców Węgier i równocześnie tworzą taką wspólnotę, która dąży do ochrony tego dziedzictwa oraz dba o interesy swoich historycznie ukształtowanych wspólnot.

Osoby przynależne do narodowości nie muszą mieć też obywatelstwa państwa, z którym jest związana dana mniejszość. Wystarczy, jeżeli identyfikują się one z daną narodowością i przynależą do wspólnoty językowej i kulturowej przez nią tworzonej (Kallai 2013, 130).

\footnotetext{
${ }^{7} \mathrm{~W}$ węgierskiej ustawie wyrażenie mniejszość etniczna odnosiło się do grupy romskiej. Stanowi ona na Węgrzech społeczność stosunkowo liczną i wyróżniającą się kulturowo. W 2012 roku Instytut Badań Społecznych TARKI przeprowadził badanie mające ustalić szacunkową liczbę Romów na Węgrzech. Badanie opierało się na monitoringu gospodarstw domowych i na odpowiedziach na pytanie o przynależność - zgodnie z tym liczbę Romów oszacowano na 440-460 tys. Na podstawie dodatkowych szacunków zewnętrznych tę liczbę zwiększono o 200-220 tys. W sumie oszacowano, że na Węgrzech mieszka 620-680 tys. Romów, co stanowi ok. 6,5\% ludności (Bernát 2014, 249). Ludności romskiej nigdy nie traktowano jako mniejszości narodowej ani narodowości. Zgodnie z polityką władz okresu socjalizmu ta grupa miała zasymilować się z ludnością węgierską. W 1979 roku ludność romska została oficjalnie uznana za „grupę etniczną” a jej status zrównano ze statusem mniejszości narodowej w ustawie z 1993 roku (Dobos 2007, 147). W języku prawnym i urzędowym do czasu uchwalenia w 2011 roku ustawy o narodowościach utrzymywano natomiast zróżnicowanie terminologiczne: stosowano stały związek wyrazowy mniejszość narodowa i etniczna, w którym wyrażenie mniejszość etniczna odnosiło się w zasadzie tylko do ludności romskiej.

${ }^{8} \mathrm{~W}$ Polsce terminem mniejszości narodowe nazywa się „,wszystkie grupy etniczne i odłamy narodowe, nieposiadające na obszarze danego państwa odrębnej, własnej państwowości, a charakteryzujące się dużym poczuciem odrębności etniczno-grupowej i dążącej do jej zachowania, poprzez pielęgnowanie tradycji, wierzeń oraz podkreślania i demonstrowania w różnych formach własnej odrębności” (Kuźnicka 2017, 168 cyt. za: Byczkowski 1976, 21). W polskiej ustawie (art. 2.1. ustawy z dnia 6 stycznia 2005 r. o mniejszościach narodowych i etnicznych oraz o języku regionalnym (Dz.U. Nr 17, poz. 141, z późn. zm.) za mniejszość narodową uważa się taką grupę obywateli polskich, która spełnia łącznie następujące warunki: a) jest mniej liczebna od pozostałej części ludności Rzeczypospolitej Polskiej; b) w sposób istotny odróżnia się od pozostałych obywateli językiem, kulturą lub tradycją; c) dąży do zachowania swojego języka, kultury lub tradycji; d) ma świadomość własnej historycznej wspólnoty narodowej i jest ukierunkowana na jej wyrażanie i ochronę; e) jej przodkowie zamieszkiwali obecne terytorium Rzeczypospolitej Polskiej od co najmniej 100 lat; f) utożsamia się z narodem zorganizowanym we własnym państwie. W Polsce występują mniejszości narodowe: białoruska, czeska, litewska, niemiecka, ormiańska, rosyjska, słowacka, ukraińska i żydowska. Jako mniejszość etniczną ustawa określa grupę obywateli polskich, spełniającą łącznie następujące warunki: a) jest mniej liczebna od pozostałej części ludności Rzeczypospolitej Polskiej; b) w sposób istotny odróżnia się od pozostałych obywateli językiem, kulturą lub tradycją; c) dąży do zachowania swojego języka,
} 


\section{ZARYS PROCESÓW HISTORYCZNYCH KSZTALTUJĄCYCH WIELONARODOWE WĘGRY}

Plemiona węgierskie przybyłe do Kotliny Karpackiej zasiedlały do ok. 902 roku tereny zamieszkałe m. in. przez plemiona Słowian, Awarów, Bułgarów i Gepidów. W XI wieku najliczniejszą grupę w kraju stanowili Węgrzy, ale mieszkało tam też wielu Słowian. $\mathrm{Na}$ obszar królestwa napływały ponadto plemiona ze wschodu. W XI wieku byli to Pieczyngowie i Oguzowie, których zadaniem była ochrona granic przed napaścią ze strony innych wschodnich plemion koczowniczych. W okresie panowania pierwszych królów z dynastii Arpadów, czyli ok. XII wieku, na teren Węgier napływała też ludność z zachodu, z krajów łacińskich (Włosi, Walonowie, Francuzi) oraz niemieckich (Sasi, Szwabowie, Flamandowie). Były to osoby pełniące zwykle różne funkcje na dworze królewskim oraz w instytucjach Kościoła. Wśród elity znajdowali się też Hiszpanie z Aragonii, Rosjanie, Serbowie, Normanowie i inni, przybywający zwykle jako świta dla królowych. W XII wieku na Węgrzech pojawiła się też grupa Arabów i Żydów, zajmujących się głównie handlem. Dla okresu średniowiecza węgierskiego charakterystyczne były zasiedlenia, których celem stały się rozwój mało zaludnionych obszarów oraz budowa miast, wsi i kopalni. Organizacją tego procesu zajmowali się często Sasi, sprowadzający do pracy ludność z ziem polskich, czeskich, morawskich i ruskich. Do Siedmiogrodu przybywała natomiast z Bułgarii ludność rumuńska9 ${ }^{9}$ W XIII i XIV wieku do kraju dotarła też duża grupa Połowców (Kumanów) i Jasów, uciekających przed Tatarami, a pod koniec XIV wieku - Serbów uciekających przed Turkami, zajmującymi Bałkany. Większa grupa Serbów napłynęła też na początku XV wieku, kiedy król węgierski oferował znaczne majątki ziemskie despocie serbskiemu, a ten zasiedlił je serbską ludnością. Ze względu na utrzymujące się niskie zaludnienie obszaru Królestwa Węgier proces przemieszczania się i osiedlania się ludności z obszarów ościennych trwał na Węgrzech dłużej niż w Europie Zachodniej, gdzie sytuacja była w miarę stabilna już na początku XIV wieku. Na Węgrzech w początkach tamtego stulecia liczba mieszkańców na $\mathrm{km}^{2}$ wynosiła 5-7 osób. W tym czasie w Europie Zachodniej, nawet po epidemii czarnej ospy, mieszkańców było wielokrotnie więcej. Pod koniec XV wieku liczba ludności Królestwa razem ze Slawonią liczyła ok. $3 \mathrm{mln}$. W późnych dekadach XVIII stulecia (lata 1784-1787) spis ludności przeprowadzony przez cesarza Józefa II Habsburga zarejestrował, że Węgry liczą 8,5 mln mieszkańców. Szczególnie słabo zaludnione były obszary, które wcześniej były okupowane przez Turków. Trudno było uzupełnić te braki tylko przez naturalny przyrost ludności, dlatego cesarz Karol III i cesarzowa Maria Teresa Habsburg (XVIII wiek) organizowali proces zasiedleń Królestwa Węgier. Do zamieszkania na Węgrzech zachęcano przede wszystkim ludność

kultury lub tradycji; d) ma świadomość własnej historycznej wspólnoty etnicznej i jest ukierunkowana na jej wyrażanie i ochronę; e) jej przodkowie zamieszkiwali obecne terytorium Rzeczypospolitej Polskiej od co najmniej 100 lat; f) nie utożsamia się z narodem zorganizowanym we własnym państwie. Do polskich mniejszości etnicznych należą Karaimowie, Łemkowie, Romowie oraz Tatarzy.

${ }^{9}$ Więcej o pochodzeniu i zróżnicowaniu ludności Węgier Wschodnich - zob. Kaczmarek 2021. 
niemiecką, ale napływały też inne narodowości, przykładowo - Serbowie. Od XVII wieku na Węgry przybywały też znaczne grupy Chorwatów, a od kolejnego stulecia Słowaków. W tym ostatnim przypadku były to $-\mathrm{z}$ jednej strony - przemieszczenia wewnątrz kraju, tj. Słowacy z Górnych Węgier przenosili się na południe, a nawet do Siedmiogrodu, a z drugiej - nowa ludność słowacka napływała na obszar Górnych Węgier. W okresie od XVII do XIX wieku na Węgry przybywali też Rumuni oraz Rusini. Ci ostatni osiedlali się zwykle małymi grupami, dlatego większość z nich dość szybko się zasymilowała. Szacuje się, że pod koniec XVIII wieku mniej niż 40\% mieszkańców królestwa stanowiła ludność węgierska (Gyémánt i Katona 2014, 181-199) ${ }^{10}$.

\section{PRAWA MNIEJSZOŚCI NARODOWYCH DO KULTURY I JĘZYKA W KRÓLESTWIE WĘGIER}

Wielość narodowości miała ogromny wpływ na funkcjonowanie kraju, jego kulturę, system prawny i administracyjny. Poszczególne grupy formowały się przez stulecia w społeczności porozumiewające się w swoim języku, z własnym prawem zwyczajowym, przywykłe do idei „samorządzenia”. Lokalne zbiory praw o tyle musiały być dostosowane do prawa krajowego, że nie mogły być z nim sprzeczne. Prawo do tworzenia takich zbiorów, obejmujących zarówno sprawy cywilne, jak i karne, miały m.in. takie lokalne wspólnoty jak narodowość seklerska i poszczególne rady seklerskie, wspólnota Sasów i rady saskie ${ }^{11}$ czy grupa Jasów i Połowców. Te prawa powstawały zazwyczaj w językach poszczególnych społeczności. Ponieważ miasta często budowała i rozwijała ludność niemiecka, to niektóre węgierskie średniowieczne statuty miejskie formułowano w języku niemieckim, jak pierwszą księgę prawną miasta Budy. Do XVII-XVIII wieku procesy sądowe odbywały się w formie ustnej, w języku narodowości stron postępowania. Duże zróżnicowanie języków i kultur ludności zamieszkującej Węgry spowodowało, że przez

${ }^{10}$ Według wyników spisu na Węgrzech żyło w tym okresie 6,46 mln ludności, w Siedmiogrodzie 1,44 mln, w Chorwacji - 0,34 mln mieszkańców. Blisko 700 tys. liczyła ludność pogranicza wojskowego, podlegająca bezpośrednio Wiedniowi. Ludność krajów Korony Węgierskiej wynosiła ok. 9,3 mln ludzi, co stanowiło 43,4\% wszystkich mieszkańców monarchii Habsburgów (łącznie 23 mln). „Spis ludności z czasów Józefa II nie odzwierciedlał czynnika narodowego, ale Węgrzy mogli stanowić tylko 3,5 mln mieszkańców Węgier i nadal byli najliczniejszym narodem, tj. stanowili około $38-40 \%$ ludności całego kraju. Pozostałe narodowości stanowiły następującą część ogólnej liczby mieszkańców: Rumuni - 1,5 mln, Słowacy $1,25 \mathrm{mln}$, Niemcy $1,1 \mathrm{mln}$, Chorwaci $0,8 \mathrm{mln}$, Serbowie $0,6 \mathrm{mln}$, Rusini $0,3 \mathrm{mln}$ oraz inne mniejsze narody, np. Ormianie. Proporcje te nie ulegały już w XIX wieku większym zmianom” (Kopyś 2018, 172-173).

${ }^{11}$ W 1437 roku powołano Unię Trzech Narodów Siedmiogrodu: Węgrów, Seklerów i Sasów. Te grupy uchwaliły, że mają równy, autonomiczny status. Społeczność seklerska przez kolejne stulecia podtrzymywała kulturę odrębności. Do utrzymania swoistej autonomiczności Seklerów przyczynił się m.in. podział Węgier, będący konsekwencją ich klęski pod Mohaczem w 1526 roku, a zwłaszcza późniejsze wydzielenie Księstwa Siedmiogrodu. Skutkiem tego ziemie zamieszkałe m.in. przez Seklerów przez kolejne stulecia funkcjonowały w sposób autonomiczny, a ta grupa utrzymała silne poczucie odrębności swojej wspólnoty. Przeprowadzone niedawno badanie socjologiczne wśród młodzieży seklerskiej potwierdziło, że ta tożsamość nadal istnieje .,Jest gdzieś we mnie wielka duma, że jestem zarówno Seklerką, jak i Węgierką (dziewczyna, Gyergyószentmiklós/ Gheorgheni) (Székely 2014, s. 10). Więcej o historii Seklerów - (Kaczmarek 2021). 
stosunkowo długi okres językiem prawodawstwa krajowego i ważnych dokumentów (przykładowo - stanowiących o prawie własności) pozostawała łacina, gwarantująca stabilność zapisów prawnych. Pozostała ona językiem wykładowym prawa na uniwersytetach do 1823 roku, a w ustawach stosowano ją do czasu Zgromadzenia Narodowego w latach 1832-1836. Następnie, do roku 1840, ustawy wprowadzano w dwóch językach: łacińskim i węgierskim, a potem - już tylko w języku węgierskim (Kaczmarek 2011, 22-25, 27-30 za: Engel 1990; Béli 2000; Kovács 1964).

Relacje między Węgrami a narodowościami stały się bardziej napięte po uchwaleniu przez parlament węgierski Ustawy II z 1844 roku o języku i narodowości węgierskiej (1844. évi II. törvénycikk a magyar nyelv és nemzetiségröl), mówiącej o tym, że język węgierski jest językiem urzędowym w całym kraju. Miał on obowiązywać we wszystkich instytucjach państwowych, w tym - w szkołach średnich. Od tego momentu możemy więc mówić o coraz intensywniejszej madziaryzacji ludności. Ten fakt wykorzystał cesarz Józef II podczas powstania antyhabsburskiego w latach 1848-1849, kiedy to - na skutek jego obietnic w zakresie rozszerzenia praw mniejszości - narodowości opowiedziały się za Austrią, przeciwko Węgrom.

Od 1863 roku w Królestwie Węgier (a kilka miesięcy później - w Siedmiogrodzie, który miał status obszaru autonomicznego) zaczęło obowiązywać skodyfikowane prawo cywilne, wprowadzone już wcześniej w Austrii. Lokalne prawa ustalone przez narodowości straciły tym samym rację bytu. Prawo austriackie uwzględniało w pewnym zakresie religijne zróżnicowanie ludności. Przykładowo: na Węgrzech nowe przepisy nie dotyczyły związków małżeńskich zawieranych przez katolików i grekokatolików, dotyczyły natomiast protestantów i Żydów, a w Siedmiogrodzie nie odnosiły się do żadnych wyznań chrześcijańskich, czyli w praktyce dotyczyły tylko Żydów (Kaczmarek 2011, 32 za: Béli 2000).

W latach 60. tematyka praw mniejszości stawała się coraz bardziej istotna w dyskursie publicznym. Tworzono memoranda, w prasie ukazywały się artykuły, coraz głośniej wybrzmiewały głosy narodowości, podnoszone czy to przez partie polityczne, czy to przez innego rodzaju stowarzyszenia i grupy społeczne. Rozpoczęto prace nad ustawą, która regulowałaby status mniejszości narodowych, formułowano dokumenty dotyczące praw Ormian (1863), Rusinów (1867), Serbów (1861) czy Słowaków (1861). Większość z wprowadzanych regulacji czy dyskutowanych projektów dotyczyła niemal wyłącznie tematu języka danej narodowości - nie brano pod uwagę praw politycznych, unikano zwłaszcza kwestii, które mogłyby - zdaniem polityków - doprowadzić do wyodrębnienia się osobnych państw (Csernus-Lukács 2020, 2-3).

Dla licznych narodowości zamieszkałych w cesarstwie Habsburgów, w tym na Węgrzech, istotny był wpis tzw. konstytucji grudniowej (Staatsgrundgesetz vom 21. December 1867, über die allgemeinen Rechte der Staatsbürger für die im Reichsrathe vertretenen Königreiche und Länder) do zbioru ustaw z 1867 roku. Artykuł 19 części drugiej stanowił, że wszystkie narodowości cesarstwa są równe i mają nienaruszalne prawo do ochrony i pielęgnowania własnej tożsamości narodowej i języka. Dalej stwierdzano tam, że państwo uznaje równość wszystkich języków stosowanych 
w danej prowincji, w szkołach, urzędach i w życiu codziennym. W prowincjach zamieszkałych przez różne narodowości miano zapewnić możliwość uczenia się w języku każdej z tych narodowości. W dokumencie austriackim stosowano dwa wyrażenia: landesübliche Sprache i Landessprache. Pierwsze miało szersze znaczenie i odnosiło się do wszystkich języków używanych w danej prowincji/kraju, drugie natomiast - do języków zwyczajowo stosowanych na obszarze podlegającym pod określoną instytucję, np. sąd czy szkołę. Prawodawca zwracał przez to uwagę, że język, jakim się należy urzędowo posługiwać, powinien być językiem faktycznie używanym na danym obszarze. Paradoks prawa austriackiego polegał na tym, że chociaż zapis konstytucji mówił o równości języków w cesarstwie, to w praktyce rząd przyjmował, że w sprawach urzędowych i w sądach należało się posługiwać językiem niemieckim. W 1868 roku na obszarze Węgier wprowadzono Ustawę XLIV o równości narodowości (1868. évi XLIV. törvénycikk a nemzetiségi egyenjogúság tárgyában), zgodnie z którą wszystkie narodowości zamieszkujące kraj miały mieć równy status. Był to więc zapis podobny do tego z konstytucji austriackiej, jednak w ustawie węgierskiej podkreślono, że językiem urzędowym, czyli oficjalnie dominującym, ma być język węgierski. Stałby się on obowiązkowo językiem debaty parlamentarnej i ustaw, językiem rządu, sądów wyższej instancji oraz lokalnych przedstawicieli administracji państwowej. Natomiast każda narodowość mogła używać swojego języka w życiu codziennym, a w pewnym zakresie - również w lokalnej komunikacji urzędowej, w radach gmin czy w sądach rejonowych. Wyjątek stanowili Chorwaci, którzy mieli znacząco rozszerzone prawa do stosowania swojego języka, w tym prawo do zabierania głosu w parlamencie węgierskim w języku chorwackim (Nagy 2020, 174-177).

Wprowadzenie ustawy XLIV z 1868 roku poprzedzało wiele dyskusji ideologicznych. Węgierski polityk József Eötvös jeszcze w 1848 roku stwierdzał, że narodowości są coraz słabsze i rozwój społeczny doprowadzi do ich wymarcia, a jedynym czynnikiem, który je jeszcze utrzymuje przy życiu, okazuje się język przez nie stosowany. Przy czym samo używanie języka nie tworzy jeszcze grupy narodowościowej, tylko ją podtrzymuje. Później jego poglądy ewoluowały do coraz bardziej liberalnych. Państwo z organami centralnymi miało być uzupełniane o struktury samorządowe realizujące potrzeby zarówno całego narodu, jak i poszczególnych narodowości. Prawa każdej z mniejszości narodowych miały być takie same jak prawa narodowości węgierskiej, a każdy obywatel miał mieć prawo do wyboru języka także w sprawach urzędowych. József Eötvös nie popierał natomiast idei autonomii opartej na podziale obszarowym lub osobowym. Z kolei przedstawiciele narodowości złożyli projekt, w myśl którego sześć najliczniejszych grup narodowych, tzw. narodów krajowych, miało uzyskać autonomie na podstawie podziału uwzględniającego województwa. W tym okresie narodziła się też idea, sformułowana przez węgierskiego polityka Ferenca Deáka, o ,jednym, niepodzielnym narodzie politycznym”, w którym każdy obywatel miał mieć równe prawa, niezależnie od tego, do jakiej narodowości należał. Ostatecznie to tę ideę wyrażono w preambule ustawy XLIV z 1868 roku. Poważna wada tego aktu polegała na tym, że obejmował on w zasadzie tylko kwestie związane z używaniem 
języka węgierskiego i języków narodowości w poszczególnych instytucjach państwa, nie uwzględniał natomiast praw społeczno-politycznych. Językiem urzędowym, stosowanym w najważniejszych urzędach państwowych, pozostawał język węgierski. Również wszystkie ustawy krajowe miały powstawać w języku węgierskim, z tym że przetłumaczono by je na języki wszystkich narodowości zamieszkujących Węgry (Kallai 2013, 111-112).

Program Węgierskiej Partii Narodowej pod koniec XIX wieku zasadniczo opierał się na liberalnym podejściu do kwestii narodowościowych, chociaż również wtedy przyjmowano, że prawa narodowości polegają na prawie do języka i kultury i nie oznaczają odrębnego statusu prawnego czy politycznego. Potem politycy węgierscy coraz mocniej ograniczali nawet te wąsko rozumiane prawa mniejszości i coraz intensywniej dążono do przymusowej madziaryzacji narodowości, ponieważ obawiano się coraz głośniej formułowanych postulatów politycznych Rumunów, Słowaków i Serbów. Ustawa XXVII z 1907 roku o szkołach niepublicznych i kościelnych (1907. évi XXVII. törvénycikk a nem állami elemi népiskolák jogviszonyairól és a községi és hitfelekezeti néptanitók járandóságairól), znana pod nazwą Lex Apponyi (od nazwiska polityka węgierskiego Alberta Apponyi), wprowadzała język węgierski również do szkół prowadzonych przez narodowości. Miała na celu m.in. wyeliminowanie niekorzystnych - zdaniem niektórych polityków węgierskich - tendencji w szkolnictwie narodowościowym. Nauczycielom takich szkół zarzucano, że nie kształcą postaw patriotycznych, a nawet kształtują postawy wrogie wobec narodowości węgierskiej, a przy tym swoim zachowaniem wskazują, że nie chcą przynależeć do państwa węgierskiego, w szkołach narodowościowych nie ma zawieszonych węgierskich symboli narodowych, nauczyciele nie uczą prawidłowo języka węgierskiego, używają podręczników niezaaprobowanych przez rząd węgierski itp. W razie stwierdzenia takich zachowań przewidziano przeprowadzanie postępowań dyscyplinarnych (Borbély 2017, 9-20).

\section{TRAKTAT W TRIANON I JEGO KONSEKWENCJE DLA MNIEJSZOŚCI NARODOWYCH}

Sytuację mniejszości narodowych na Węgrzech po pierwszej wojnie światowej regulowały punkty 54-60 traktatu podpisanego w Trianon w 1920 roku. Węgry zobowiązano w nim do zapewnienia ochrony życia i wolności wszystkim mieszkańcom kraju, bez różnicowania ze względu na urodzenie, narodowość, język, rasę czy wyznanie. Odpowiednio do tego rząd węgierski wprowadził w 1923 roku rozporządzenia zapewniające edukację w językach mniejszości, możliwość stosowania własnego języka w działalności kulturalnej oraz w administracji państwowej. Chęci wprowadzania jak najlepszych rozwiązań dla narodowości na Węgrzech towarzyszyła niewątpliwie intencja poprawy sytuacji diaspory węgierskiej, która znalazła się poza granicami ojczyzny. Sytuacja pogorszyła się w drugiej połowie lat 30., kiedy rząd Gyüli Gömbösa w miejsce szkół jednojęzycznych wprowadził dla narodowości szkoły dwujęzyczne. Wraz ze wzrostem na Węgrzech wpływów Niemiec faszystowskich komplikowała się też sprawa autonomiczności ludności niemieckiej (Bindorffer, Dóczé i Kállai 2020, 24). 
Mimo stosunkowo korzystnych rozwiązań prawnych siła narodowości w tym okresie znacznie osłabła. Spośród nielicznych przedstawicieli mniejszości, którzy nadal mieszkali w granicach Węgier, wielu uległo asymilacji. Utrzymanie autonomicznej kultury i języka było trudne, ponieważ: 1) narodowości były rozproszone, 2) członkowie narodowości w większości byli co najmniej dwujęzyczni, więc często używali języka węgierskiego, 3) dostęp do szkolnictwa w językach mniejszości okazywał się ograniczony, chociażby ze względu na brak nauczycieli, 4) zawierano liczne małżeństwa mieszane. W latach 1910-1941 liczba ludności Węgier potrianońskich zwiększyła się o 22\%. W tym samym okresie liczba osób, dla których język węgierski nie był językiem ojczystym, zmalała o $25 \%$, w tym Serbów - o 79\%, Słowaków - o 54\%, Rumunów - o 50\%, Chorwatów - o 40\%, Słoweńców - o 30\% i Niemców - o 14\% (Olasz 2014, 251-255).

Osobną kwestią były dyskryminujące rozporządzenia dotyczące przede wszystkim ludności żydowskiej wprowadzone w okresie między I a II wojną światową. Do pierwszych tego typu działań należało wprowadzenie w 1920 roku Ustawy XXV o zasadach rekrutacji na uczelnie wyższe (1920. évi XXV. törvénycikk a tudományegyetemekre, a müegyetemre, a budapesti egyetemi közgazdaságtudományi karra és a jogakadémiákra való beiratkozás szabályozásáról) zwanej potocznie ustawa numerus clausus. W § 3 stwierdzano, że o przyjęciu na studia decyduje ostatecznie Rada Wydziału, jednakże powinna ona wziąć pod uwagę proporcje narodowościowe (ludność żydowska bezskutecznie domagała się wtedy traktowania jej jako wspólnoty religijnej, a nie - jako grupy narodowościowej):

Przy udzielaniu zezwolenia oprócz wymagań w zakresie wykazania się moralnością i lojalnością narodową należy z jednej strony wziąć pod uwagę zdolności kandydata, z drugiej strony należy zadbać, żeby proporcje młodzieży przynależącej do poszczególnych grup etnicznych i narodowości były odpowiednie do proporcji krajowych danych grup etnicznych i narodowości.

U podstaw tego zapisu nie leżała natomiast ogólna polityka wobec mniejszości narodowych - chodziło raczej o interes polityczny bazujący na antysemityzmie istniejącym w społeczeństwie: ten zapis uderzał faktycznie w grupę młodzieży żydowskiej. W 1920 roku ludność żydowska stanowiła 6\% społeczności na Węgrzech, z tego przed pierwszą wojną światową odsetek młodzieży żydowskiej wynosił około $25 \%$ ogólnej liczby studentów, a w 1918 roku było to już 36\%. Natomiast studenci innych narodowości nie przekraczali w tym okresie proporcji wymaganych ustawą, więc ograniczenia w zasadzie ich nie dotknęły. Zresztą zniesiono je w 1928 roku, pod naciskiem opinii międzynarodowej, tyle że już w połowie lat 30 . zaczęto wprowadzać kolejne restrykcje w tym zakresie, które oficjalnie przypieczętowano serią ustaw antyżydowskich, wprowadzanych od 1939 roku (Kovács 2011, 29-30).

\section{POLITYKA NARODOWOŚCIOWA W OKRESIE SOCJALIZMU}

Po II wojnie światowej doszło do kolejnej fali przemieszczeń ludności. Z kraju wysiedlono znaczną grupę Niemców, a Słowaków i Węgrów przesiedlano w związku 
z przesunięciami granic, co jeszcze bardziej osłabiało mniejszości, które pozostały na Węgrzech. Socjalistyczne prawo lat 50. kładło akcent na ideę jedności narodowej, w związku z tym, mimo deklaracji zawartych w programie Węgierskiej Partii Pracujących z 1948 roku, faktycznie nie zabezpieczało praw narodowości. Dążono do zatarcia różnic między „większością” a mniejszościami narodowymi, co z czasem miało doprowadzić do zaniknięcia różnic między ludnością zamieszkującą Węgry. W Ustawie X z 1954 roku o Radach Narodowych (1954. évi X. törvény a tanácsokról) stwierdzono, że Rada Narodowa współdziała w realizacji lokalnych zadań o charakterze społecznym, gospodarczym i kulturalnym, w tym w $\S 6$ ust. 3, pkt h) zawarto dość enigmatyczną wskazówkę, że „Rada zapewnia realizację praw narodowości”. Poza tym ogólnym założeniem państwo nie przywiązywało dużej wagi do kwestii mniejszości narodowych.

Mimo niesprzyjających okoliczności powstawały i funkcjonowały różnego typu organizacje zrzeszające ludność z mniejszości narodowych. I chociaż ich działalność ograniczała się do promowania kultury i organizowania edukacji, bez jakichkolwiek praw politycznych - to jednak ich istnienie niejako zmuszało rząd do zauważenia, że mniejszości w ogóle na Węgrzech istnieją. Z czasem wszystkie organizacje podporządkowano komunistycznej administracji państwowej, co pozwoliło skuteczniej kontrolować ich działalność. Po powstaniu budapeszteńskim w 1956 roku, gdy minął początkowy okres nasilonego terroru, władze komunistyczne zmieniły taktykę i różnymi sposobami próbowały uzyskać akceptację kolejnych warstw społeczeństwa. Jednym z narzędzi stała się bardziej przyjazna polityka wobec mniejszości. Rozpoczęto organizację i rozbudowę instytucji wspierających mniejszości narodowe oraz umożliwiono im delegowanie swoich przedstawicieli do parlamentu. Jednak już pod koniec 1958 roku w partii sformułowano opinię, że „nacjonalizm” stanowi jedno z głównych zagrożeń w procesie budowy socjalizmu. Zgodnie z linią polityczną organizacje narodowościowe miały więc za zadanie przede wszystkim podejmować działania na rzecz ,socjalistycznej edukacji politycznej i kulturalnej”. W 1960 roku szkoły podstawowe i średnie z edukacją w języku narodowości przekształcono w szkoły dwujęzyczne.

W latach 70., m.in. na skutek coraz głośniejszego podnoszenia kwestii mniejszości narodowych na forach międzynarodowych, program polityczny wobec narodowości zamieszkałych na Węgrzech zaczął się zmieniać. Zwiększyła się liczba organizacji i struktur, ministrowi kultury powierzono dbanie o kulturę mniejszości narodowych, ministrowi edukacji - o ich szkolnictwo. Organizacje mniejszości zaczęły mieć też pewne prawa polityczne, które początkowo ograniczały się do konsultacji i doradztwa. W latach 80 . przy Ministerstwie Kultury i Edukacji utworzono Komisję Doradczą ds. Narodowości, składającą się z działaczy państwowych i przedstawicieli społecznych organizacji mniejszościowych. Rozbudowano sieć organizacji działających w małych miejscowościach, ich znaczenie umniejszał jednak fakt, że - zgodnie z modelem socjalistycznym - struktury lokalne nie podejmowały niezależnych decyzji. W drugiej połowie lat 80. rola organizacji zaczęła ewaluować w kierunku ochrony praw mniejszości, a ich przedstawiciele zaczęli pełnić funkcję politycznych reprezentantów tych grup. Coraz 
częściej wskazywano, że prawa mniejszości narodowych powinny być realizowane również poza obszarem kultury (Dobos 2007).

\section{DEMOKRATYZACJA SYSTEMU I POWRÓT DO POLITYKI NARODOWOŚCIOWEJ DETERMINOWANEJ PRZEZ TRAKTAT W TRIANON}

Impulsem do poważniejszego potraktowania kwestii mniejszości narodowych na Węgrzech pod koniec lat 80 . była pogarszająca się sytuacja węgierskiej diaspory w Rumunii. W 1988 roku rozpoczęto na Węgrzech prace nad nowoczesnym prawem regulującym status mniejszości narodowych. Wzięli w nich udział zarówno naukowcy, jak i przedstawiciele związków mniejszości. Zwrócono wtedy uwagę, że chociaż w obowiązującej ciągle konstytucji z 1949 roku istnieje zapis o równości narodowości żyjących na obszarze Węgier, ich prawie do języka, edukacji i kultury, to faktycznie brakuje regulacji ustawowych, które gwarantowałyby realizację tych praw. Równocześnie rozpoczęto przekształcanie dotychczasowych związków i organizacji w nowoczesne struktury, zdolne do faktycznej reprezentacji mniejszości na szczeblu lokalnym.

Po przemianach systemowych z 1989 roku rozpoczęto intensywne prace nad zwiększeniem praw mniejszości narodowych. W tym samym roku powstała nowa instytucja - Kolegium Narodowości. Miała ona koordynować działania różnych organizacji państwowych i społecznych działających na rzecz mniejszości narodowych na Węgrzech oraz diaspory węgierskiej za granicą. W 1990 roku utworzono natomiast odrębny Urząd ds. Mniejszości Narodowych i Etnicznych.

Oprócz działań rządowych, fundamentalne znaczenie miała aktywizacja społeczności lokalnych. Po ogłoszeniu w 1989 roku wolności zrzeszania się rozpoczęła się budowa społecznych organizacji mniejszościowych, których działalność od 1991 roku była finansowana z funduszy państwowych. Już w 1990 roku te organizacje utworzyły wspólne ciało reprezentujące ich interesy, tzw. Unię Węgierskich Mniejszości Narodowych, od kolejnego roku funkcjonujące jako tzw. Okrągły Stół Węgierskich Mniejszości Narodowych i Etnicznych. W ramach tej grupy pracowano wraz z rządem nad projektem nowej ustawy o mniejszościach narodowych. W przestawionym projekcie bardzo dużą rolę otrzymały samorządy mniejszości narodowych. Miałyby szerokie prawa administracyjne i stanowiłyby centra dla swoistych autonomii kulturowych, m.in. ustalałyby podstawę programową dla szkół narodowościowych, wybierały ławników do tzw. Kolegium Mniejszości Narodowych przy Sądzie Najwyższym i delegowały kandydatów do Zgromadzenia Narodowego (Kállai 2013, 114).

W dyskusjach nad projektem powracano do najlepszych tradycji oraz idei najkorzystniejszych dla narodowości i wyrażonych w ustawach wprowadzanych w XIX wieku. W przeciwieństwie do - pojawiającej się w niektórych okresach historii Węgier - idei madziaryzacji, nowe prawo miało przeciwdziałać asymilacji narodowości: wspierałoby je strukturalnie w pielęgnowaniu własnej kultury i utrzymaniu odrębnej tożsamości. Jednakże, w ocenie samych mniejszości, ustawa, która ostatecznie weszła w życie w 1993 roku, nie spełniała w pełnym zakresie oczekiwań i pozostawiała wiele kwestii 
nierozwiązanych. Prawodawcy nie uwzględnili w wystarczającym stopniu faktu, że 13 wymienionych narodowości znacząco się różni, zarówno pod względem wielkości, jak i specyfiki - przez co bardzo trudno uregulować ich funkcjonowanie w jednym akcie prawnym. Wiele nierozwiązanych kwestii zapowiadało problemy, których nie udało się zniwelować ani poprzez późniejsze zmiany w ustawie, ani poprzez wprowadzenie w 2011 roku nowej Ustawy o narodowościach (Molnar 2017, 198-200).

Przy okazji poszukiwań najlepszych sposobów uregulowania sytuacji mniejszości narodowych nieustannie zwraca uwagę fakt, że wszelkie rozwiązania przyjmowane na Węgrzech po podpisaniu traktatu w Trianon w 1920 roku były determinowane przez potrzebę poprawy sytuacji diaspory węgierskiej z krajów ościennych ${ }^{12}$. Znajduje to odzwierciedlenie zarówno w treści ustaw i rozporządzeń, jak i w stosowanej terminologii. Zamiana terminu mniejszość narodowa na narodowość zawiera ogromny ładunek emocjonalny i jest faktycznie konsekwencją dramatycznych zapisów traktatu z Trianon oraz próbą załagodzenia jego skutków dla kolejnych pokoleń Węgrów.

\section{BIBLIOGRAFIA}

Babiński, G. 1998. „Etniczność”. W Encyklopedia socjologiczna. T 1: A-J, red. W. Kwaśniewicz. Warszawa: Oficyna Naukowa.

Béli, G. 2000. Magyar jogtörténet. A tradicionális jog. Budapest-Pécs: Dialóg Campus Kiadó.

Bieńkowska-Ptasznik, M. 2007. „Tożsamość etniczna jednostki w kontekście pogranicza”. W Etniczność i obywatelskość w Nowej Europie. Konteksty edukacji międzykulturowej, red. J. Nikitorowicz, D. Misiejuk, i M. Sobecki. Białystok: Wydawnictwo Uniwersyteckie Trans Humana, 324-333.

Bindorffer, G., N. Dóczé, i E. Kállai. 2010. „A magyarországi nemzetiségi közösségek történelme és jelene”. W Ajövevényektöl az államalkotó tényezökig. A nemzeti ségi közösségek múltja és jelene Magyarországon, red. T. Gyulavári, i E. Kállai. Budapest: Országgyülési Biztos Hivatala, 49-143.

Byczkowski, J. 1976. Mniejszości narodowe w Europie 1945-1974. Opole: Instytut Śląski.

Csernus-Lukács, S. 2020. „Nemzetek vagy nemzetiségek? Törvények és törvénytervezetek a nemzetiségi egyenjogúságról az 1860-as években”. Erdélyi Jogélet 3: 3-25.

Czuczor, G., i J. Fogarasi. 1862-1874. A magyar nyelv szótára. Magyar Tudományos Akademia megbízásából kész. Pest: Emich.

Dobos, B. 2007. „Kisebbségpolitika és kisebbségpolitikai intézményrendszer Magyarországon 1948-1993 között”. Regio 3: 147-172.

\footnotetext{
${ }^{12}$ Jak zauważają Dominik Héjj i Bogusław Olszewski $(2015,571)$ : dbanie o Węgrów poza granicami jest dla obecnego rządu absolutnym priorytetem. Znamienny jest fakt, że przed Parlamentem w Budapeszcie nie wisi flaga Unii Europejskiej, a flaga Siedmiogrodu. Niezwykle dyplomatycznie thumaczy się to tym, że jest to efekt niepodejmowania przez UE niezbędnych działań wobec ochrony mniejszości węgierskiej w Rumunii. Flagi Siedmiogrodu wiszą również w wielu urzędach, zarówno w Budapeszcie, jak i w mniejszych miasteczkach. Interesujące jest też zachowanie Węgier w sprawie ewentualnej akcesji Serbii do Unii Europejskiej. Oczywiste jest, że premier Viktor Orbán mocno lobbuje na rzecz wstąpienia Serbii do europejskich struktur, aby zwiększyć w ten sposób możliwość oddziaływania na serbskie władze.
} 
Engel, P. 1990. Beilleszkedés Európába, a kezdetektől 1440-ig. Budapest: Háttér Lap és Könyvkiadó.

Gyémánt, R., i T. Katona. 2014. Demográfia. Pólay Elemér Alapítvány. https://regi.tankonyvtar.hu/hu/ tartalom/tamop425/2011_0001_547_Demografia/index.html (5 listopada 2021).

Héjj, D. 2018. „Węgierska diaspora i polityka narodowościowa jako element rywalizacji politycznej na Węgrzech”. W Polityka migracyjna w obliczu wspólczesnych wyzwań, red. H. Chałupczak, M. Lesińska, E. Pogorzała, i T. Browarek. Lublin: Wydawnictwo UMCS, 229-248.

Héjj, D., i B. Olszewski. 2015. „Polityka etniczna Węgier”. W Polityka etniczna współczesnych państw Europy Środkowo-Wschodniej, red. H. Chałupczak, R. Zenderowski, i W. Baluk. Lublin: Wydawnictwo UMCS, 531-573.

Janusz, G. 2008. „Definiowanie mniejszości w dokumentach międzynarodowych i aktach prawa wewnętrznego". Annales Universitatis Mariae Curie-Skłodowska. Sectio K, Politologia 15 (2): 95-124.

Kaczmarek, K. 2011. „Lingua legis w aspekcie translatologicznym węgiersko-polskim i polsko-węgierskim”. Comparative Legilinguistics 6: 5-228.

Kaczmarek, K. 2021. „Autonomie terytorialne i kulturowe w Siedmiogrodzie. Dążenia i interpretacje”. Historia Slavorum Occidentis 4: 97-115.

Kállai, E. 2013. „A kisebbségi joganyag és annak változásai az elmúlt negyedszázadban Magyarországon”. W A közép-európaiság dicsérete és kritikája, red. C. Fedinec, Z. Ilyés, A. Simon, i B. Vizi. Bratysława: Kalligram Kiadó, 108-135.

Kopyś, T. 2018. Historia Wegier 1526-1989. Kraków: Wydawnictwo Avalon.

Kovács, M.M. 2011. „Numerus clausus Magyarországon, 1919-1945. W Jogfosztás - 90 éve. Tanulmányok a numerus claususról, red. J. Molnár. Budapest: Nonprofit Társadalomkutató Egyesület, 29-59.

Kovács, F. 1964. A magyar jogi terminológia kialakulása. Budapest: Akadémiai Kiadó.

Kuźnicka, D. 2017. „Mniejszość etniczna a mniejszość narodowa w Polsce - analiza porównawcza na przykładzie Łemków i Żydów”. W Aktualne problemy ochrony wolności i praw mniejszości w Polsce i na świecie, red. J.B. Banach-Gutierrez, i M. Jabłoński. Wrocław: E-Wydawnictwo. Prawnicza i Ekonomiczna Biblioteka Cyfrowa. Wydział Prawa, Administracji i Ekonomii Uniwersytetu Wrocławskiego, 165-185. Molnar, S.J. 2017. „Az 1993-as magyarországi kisebbségi törvény parlamenti vitája”. Regio 25 (3): 182-202.

Nagy, N. 2020. „Variációk egy témára: a nemzetiséginyelvi egyenjogúság szabályozási formái az osztrákmagyar monarchiában". W Nemzetiségi-nyelvi szuverenitás a hosszú 19. században, jogtörténeti értekezések 46, red. N. Nagy. Budapest: Gondolat Kiadó.

Olasz, L. 2014. „Az etnikai térszerkezet változása Magyarországon a két világháború között”. W Kulturális és társadalmi sokszinüség a változó gazdasági környezetben, red. J.T. Karlovitz. Komárno: International Research Institute s.r.o., 251-256.

Romsics, I. 2018. Historia Węgier. thum. A. Barszczewska, S. Brzeziński, i M. Sagata. Poznań: Media Rodzina. Sadowski, A. 1973. „Pojęcie grupy etnicznej w socjologii”. Studia Socjologiczne 4: 186.

Székely, L. 2014. „Az Erdélyi Fiatalok Mindennapi Nemzettudata”. W Magyar identitás határon innen és túl, red. L. Székely. Budapest: Új Ifjúsági Szemle Alapítvány, 5-14.

Wrońska, I. 2014. „Specyfika pojęcia «przynależność do Narodu Polskiego» w stosunkach międzynarodowych - uwagi na tle realizacji ustawy o Karcie Polaka przez polskie służby konsularne”. W Wybrane zagadnienia wspótczesnego prawa konsularnego (z perspektywy prawa i praktyki międzynarodowej oraz polskiej), red. P. Czubik, i W. Burk. Kraków: Instytut Multimedialny. 


\title{
Ethnic Minority or Nationality? Hungary's Modern Terminological Policy as a Reflection of a Thousand Years of Tradition of a Multinational State and as a Consequence of the Trianon Treaty.
}

Keywords: Hungary, ethnic minority, nationality, terminological policy.

\begin{abstract}
The goal of this article is to identify the causes of terminological changes in Hungary's most recent legislation on the ethnic minorities inhabiting the country. It will also demonstrate the link between the current Hungarian government's terminological policy and the situation of Hungarian diasporas outside the country's borders. In particular this concerns two terms - ethnic minority and nationality. The article highlights the historical processes affecting the formation of a multinational and multilingual Hungary and of a legal system reflecting the co-existence of multiple nationalities and languages throughout the territory, as well as the points of conflict and attempts to introduce solutions either safeguarding the various nationalities' interests or establishing the dominance of the Hungarian nationality and language.

Following the change of the political system in the late ' 80 s the Hungarian government undertook numerous steps to improve the situation of the Hungarian minorities living outside the motherland since the signature of Trianon Treaty in 1920. This policy also impacted the situation of national minorities inhabiting Hungary. Works began on a new, modern law governing the status of national minorities, to provide an example for other countries to follow and an argument for Hungary in negotiations over the status of Hungarian minorities in neighbouring countries. The debate on the draft bill on national minorities, ultimately passed in 1993, saw a return to the best traditions and the most nationality-friendly ideas expressed in $19^{\text {th }}$ century legislation. In contrast with the Magyarizaton idea surfacing in some periods of Hungarian history, the new law was to counteract the assimilation of the various nationalities, instead providing them with structural support in nurturing their own cultures and maintaining a separate identity. The new Hungarian Constitution of 2011 replaced the previously used term 'national minority' with 'nationality'. Legislation enacted after that date has consistently used the term 'nationality', as reflected in the title of the new 'Nationalities' Act passed already in that same year. This is an intentional propaganda move. The goal of the terminological change is the symbolic elevation of the status of Hungarian populations living outside the motherland and call attention to the fact that Hungary regards them as an inseparable part of the one Hungarian nation.
\end{abstract}

